non-competitive athletes is increasing. Doctors seeing well muscled patients of either sex should always bear in mind the possibilities of misuse of these drugs and be aware of their consequences.

\section{H M PERRY Registrar B N C LITTLEPAGE Director}

Department of Public Health Medicine,

West Glamorgan Health Authority,

Swansea SA1 $5 \mathrm{AQ}$

1 Corder BW, Dezelaky TL, Toohey JV. Trends in drug use behaviour at central Arizona high schools. Arizona fournal of Health, Physical Education, Recreation, and Dance 1975;18:10-1.

Buckley WE, Yesalis C, Friedl KE, Anderson WA, Streit AL, Wright JE. Estimated prevalence of anabolic steroid use among male high school seniors. $¥ A M A$ 1988;260:3441-5.

3 Perry HM, Wright D, Littlepage BNC. Dying to be big: a review of anabolic steroid use. Br 7 Sport Med (in press)

4 Atkins P. The power behind the muscle. Standing Committee on Drug Abuse Nezusletter 1989 July/ August: $2-4$
5 Sklarek HM, Mantovani RP, Erens E, Heisler D, Neiderman MS, Fein AM. AIDS in a body builder using steroids. N Engl f Med 1984;311:1701.

Acott MJ, Scott MJ Jr. HIV infection associated with injections of anabolic steroids. 1989;262:207-8

7 Brower KJ, Blow FC, Young JP, Hill EM. Symptoms and correlates of anabolic-androgenic steroids dependence. Br I Addict 1991;86:759-68.

Pope HG, Katz DL. Homicide and near homicide by anabolic steroid users. 7 Clin Psychiatr 1990;51:28-31.

9 Pope HG, Katz DL. Affective and psychotic symptoms associated with anabolic steroid use Am f Psychiatry 1988;145:487-90.

10 Goldman B. Death in the locker room. New York: Century, 1986.

1 Haupt HA, Rovere GD. Anabolic steroids: a review of the literature. Am J Sports Med 1984;12 469-84

12 Haffner SM, Kushwaha RS, Foster DM. Studies on the metabolic mechanism of reduced HDL during anabolic steroid therapy. Metabolism 1983;32:413-20.

13 Webb OL, Laskarzarzewski P.M, Glueck CJ. Severe depression of HDL cholesterol levels in weightlifters and body builders by self administered exogenous testosterone and anabolic androgenic steroids. Metabolism 1984;33:971-5.

14 Winwood PJ, Robertson DAF, Wright R. Bleeding oesophageal varices associated with anabolic steroid use in an athlete. Postgrad Med f 1990;66:864-5.

15 Sellers WFS, Culwick MD, Whiting RF. Anabolic steroids and anaesthesia. Anaesth Intensive Care 1991:19:616.

16 Petting KA. Association of anabolic steroids and avascular necrosis of femoral heads. Am 7 Sport Med 1991;19:96-7.

17 Goldberg L, Bosworth GE, Bents RT, Trevisan L. Effect of an anabolic steroid education program on knowledge and attitudes of high school football players. 7 Adolesc Health Car 1990;11:210-4.

\title{
Information for patients
}

\section{Writing simple English is difficult, even for doctors}

The highly paid journalists on the Sun and the Daily Mirror claim that they would have no difficulty if asked to swop jobs with their colleagues on the Times and the Telegraph. The highbrow leader writers on the broadsheets would have many more problems writing for a mass readership. It isn't easy.

Part of the problem is that most people-and that means most patients-don't read much. They watch television, listen to the radio, and page through magazines, but they don't read for information. The response of doctors, teachers, and academics to a problem may often be to look it up in a reference book. People in many other walks of life will ask someone-friends or family. The popularity of telephone help lines and information services shows that for many people a spoken word seems more helpful than a written one.

These comments have practical implications for doctors who want to set about preparing written material for their patients. Much of what is offered to them at present is of disappointing quality - as is clearly shown by three studies in this week's BMf (pp 1263, $1266,{ }^{2}$ and 1294). Information leaflets and consent forms were found to be poorly designed, and many were written in language that failed the standard tests for readability.

So how should health professionals set about writing material for people who don't read much? Design is important. In the commercial world information leaflets are heavily illustrated, with short paragraphs in large print and lots of space on the page. For the text the basic rules are well established: short words, short sentences, avoid the passive voice, and so on-the article by Tim Albert and Stephanie Chadwick explains it all very clearly. ${ }^{2}$

Even when tackled on the basis of this advice, however, the task is not easy. Anyone planning to design a leaflet, a consent form, or a questionnaire should set aside a lot of time. It may be only 200 words long, but that doesn't mean it can be done in one evening over a couple of drinks. Producing clear, unambiguous material that people will use is one of the most highly paid jobs in journalism - and for good reason. All too often doctors think they can turn their hands to this sort of work without any training or practice. They can't, and good intentions are not enough.

My advice is to get help from someone who has done it before. Look at the information handouts produced by your local health authority, by local charities, and so on. Find someone who seems to produce attractive material and ask if he or she will advise you. Draft what you have to say; show it to your adviser and anyone else whose opinion you respect. You need feedback on several aspects. Is the material free of factual errors (important for a consent form, for example); is it clear and simple to follow; is it attractive and not offputting? Once you have a final draft version you should pilot it on a sample of real consumers and listen to what they have to say.

Does that all sound difficult? Time consuming? Expensive? It is, and that's why so much material given to patients is so awful.

Associate Editor, $B M \mathcal{F}$

TONY SMITH

1 Priestley KA, Campbell C, Valentine CB, Denison DM, Buller NP. Are patient consent forms for research protocols easy to read? $B M 71992 ; 305: 1263-4$

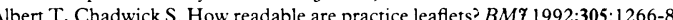

3 Bennett J, Bridger P. Communicating with patients. BMF 1992;305:1294.

\section{Correction}

Drugs and exercise testing

An editorial error occurred in this editorial by Teri Millane and David Ward (31 October, $p$ 1043). The words "Drugs may be stopped" were omitted from the second sentence of the fifth paragraph. It should read: "These patients require further investigation, the urgency of which may be assessed by an exercise test on drugs. Drugs may be stopped if the angina is infrequent." 